\title{
Improving Active Learning Time on Physical Education Using Movement Education Model
}

\author{
Nana Sutisna ${ }^{1,2, *}$ \\ ${ }^{1}$ Universitas Pendidikan Indonesia, \\ ${ }^{2}$ Universitas Galuh Ciamis \\ Bandung, Indonesia \\ *nana.sutisna@unigal.ac.id
}

\author{
Adang Suherman, Amung Ma'mun, Mulyana Mulyana \\ Universitas Pendidikan Indonesia \\ Bandung, Indonesia
}

\begin{abstract}
The purpose of this study was to determine the curriculum model in order to increase the active learning time. The research method used was a quasi-experimental posttest only design randomized control group design. The sample of this study was the seventh grade students of Junior high school Negeri 1 Baregbeg which amounted to 40 people with cluster random sampling technique. The instrument used was an instrument that adopted from the results of Suherman's research. The results of this study indicate that: There is a significant influence on the implementation of the movement model to increase the active time to study physical. Data shows that from three times data collection, the results obtained indicate an increase.
\end{abstract}

Keywords - active learning time; movement education; physical education

\section{INTRODUCTION}

National issues and even in several Asian and European countries, the level of fitness is widely discussed, especially among teenagers. The Australian State debate about obesity, this is because one of them is caused by a lack of time for physical education in the curricula. Physical activity in the UK is also being discussed. One study related to this is about physical education. Physical education is expected to contribute to physical activity [1].

Research on physical education models that can instil habits to do activities outside of learning. This research was conducted in China with the aim that young people understand that there is a need to familiarize themselves in life to practice physical activity [2].

The country of Indonesia is one of the countries in Asia which is a densely populated, fitness issues should be a special concern for the government. National education through the formulation of the curriculum, must be used as a medium in order to play an active role in creating a fit degree for the community. Society must be given understanding, how important physical activity for life is in supporting fitness. Explained in his study entitled "The Effect of a Comprehensive School of Physical Activity Program on Physical Activity and Health-Related Fitness in Children of Low-Income Families" explained the impact of the Comprehensive School Physical Activity Program (CSPAP) "Towards physical activity and health-related fitness (HRF) [3]. Other studies focused on the level of fitness of children of primary school age are carried out. The topic of this study is that the aim is to test the hypothesis that involvement in a physical fitness program will have a positive impact on fitness related to health and blood fat levels in children with low fitness.

Whose research was about Investigation of Fitness Education Model's Implementation Effects [2]. One conclusion was stated, "Most students $(76.6 \%)$ thought the" Physical Fitness "course was helpful to cultivate future exercise habits." (P.571). These conclusions explain that most students $(76.6 \%)$ consider that physical fitness training is very helpful to foster exercise habits in the future. The research can be said that if each student understands that fitness is important, then when learning to teach the teacher will look more active. Active students in the teaching and learning process will help achieve learning objectives.

Indonesia as a population that is densely populated, will at least have an impact on the large number of people who have a low fit. Research conducted by Bappenas, suggested that of 4,747 Yogyakarta junior high school students and 2\% in Bantul district were obese. The results of a study released on the website www.obesitasindonesia.org in January 2015 stated that obesity in Indonesia is in the top 10 in the world. The prevalence of $28 \%$ obesity affects adults and $47 \%$ of children and adolescents. This condition attracted the attention of the author to examine the existing problems, so that it is expected to contribute to the development of knowledge and community life.

Physical education curriculum can be used as the spearhead as a solution to people's fitness problems. The curricular curriculum that is oriented towards understanding motion, lifelong exercise, is the right media to be used as a socialization to the community so that it enters into a habit of exercise. The curricular is expected to increase the community's participation in exercise. The motion experience gained by students in physical education is an important contributor to increasing the number of participants in the physical activity and sports, student welfare and health $[4,5]$.

Instilling habits for physical activity can be initiated by active students during the teaching and learning process. Students have high active time during the KBM process, it is possible to have an impact on habits outside school hours. On 
this basis, it is necessary to design a curriculum that makes students actively active during the teaching and learning process.

Physical education or also called Physical education is education of and through movement. Keywords in the definition, namely 1) Education, 2) Through and about (through and of), and 3) Movement. These words mean that physical education is an educational process through the movement so that students can increase their fitness level [6].

The development of physical education in Indonesia can be grouped into two stages: traditional views and modern views. This view occurred due to the understanding of human beings consisting of two components. That is physical and spiritual. The first understanding is that the physical is separate from the spiritual. The second understanding that physical and spiritual one is inseparable. Based on these two understandings, it affects the notion of physical education. Physical is separate giving birth to understanding that physical education is merely physical education or as a complement, balance, or harmonizing spiritual education [7].

The purpose of the guards is very clear and measurable. The aim of the training is to achieve a fit degree for every child he teaches. Fitness is the end of the process of physical education. The movements that are used as media must be able to create students who have a good level of physical fitness. Physical education means the purpose of education both longterm (objective) and short-term (objectivity)." Physical education as well as a process through motion, but physical education is also a process that tries to harmonize all the elements that are in human beings. The elements that exist in human beings are like soul and body. Both elements must be harmonized through physical education.

Physical education is directed at achieving harmony between growth and development. Students in the end through physical education have strong physical and mental. The soul is a mental development that exists within each individual. Physical education assumes that the soul must be developed through motion so that one's soul is strong and dynamic in responding to life. Physical is physical growth. Physical must be improved and grown well through the movements that exist in physical body.

Physical education must ultimately be able to help characterize the soul and build physically every Indonesian society [6]. Indonesian society is built through physical movement. Indonesian society is formed into a civilized nation, a strong nation both soul and body so that it becomes a nation that is respected by other nations in the world. Realizing physical education goals, as a tool to develop physical skills that can increase participation in living activities, develop physical fitness and live actively in the environment, develop knowledge and understanding of physical, social, physical fitness, the principles of motion science, and towards relationships between training and life, a curriculum model is needed that can help in achieving it all [8]. The researcher tried to solve it all by trying the curriculum of the movement model. This model's curriculum programs are as follows:
TABLE I. CURRICULUM PROGRAM

\begin{tabular}{|l|l|l|}
\hline 1 & $\begin{array}{l}\text { 1. Introduction (Pray, absenteeism, warming } \\
\text { up) } \\
\text { 2. Core (service under volleyball game, } \\
\text { games) } \\
\text { 3. Cover (Evaluation, relaxation, prayer) }\end{array}$ & $\begin{array}{l}2 \text { x } \\
\text { minute }\end{array}$ \\
\hline 2 & $\begin{array}{l}\text { 1. Introduction (Pray, absenteeism, warming } \\
\text { up) } \\
\text { 2. Core (Service for volleyball games, } \\
\text { games) } \\
\text { 3. Cover (Evaluation, relaxation, prayer) }\end{array}$ & $\begin{array}{l}2 \mathrm{x} 35 \\
\text { minute }\end{array}$ \\
\hline 3 & $\begin{array}{l}\text { 1. Introduction (Pray, absenteeism, warming } \\
\text { up) } \\
\text { 2. Core (front roll, games) } \\
\text { 3. Cover (Evaluation, relaxation, prayer) }\end{array}$ & $\begin{array}{l}2 \mathrm{x} 35 \\
\text { minute }\end{array}$ \\
\hline 4 & $\begin{array}{l}\text { 1. Introduction (Pray, absenteeism, warming } \\
\text { up) } \\
\text { 2. Core (back roll, games) } \\
\text { 3. Cover (Evaluation, relaxation, prayer) }\end{array}$ & $\begin{array}{l}\text { x 35 } \\
\text { minute }\end{array}$ \\
\hline
\end{tabular}

\section{METHODS}

The method used in this research is the experimental method. The sample is students of SMP Negeri 1 Baregbeg class VII, amounting to 40 people.

\section{RESULTS AND DISCUSSION}

Based on the data obtained in the field, the authors draw the following. This table is the data obtained by the researcher, the data collection was done three times. The mean values of T1, $\mathrm{T} 2$, and $\mathrm{T} 3$, indicate that they are increasing so that this shows the number of active learning from meetings 1,2 , and 3 , has increased.

TABLE II. RESULTS

\begin{tabular}{|c|c|c|c|c|c|c|}
\hline \multirow{2}{*}{ No } & \multicolumn{2}{|c|}{ Test 1 } & \multicolumn{2}{c|}{ Test 2 } & \multicolumn{2}{c|}{ Test 3 } \\
\cline { 2 - 7 } & $\boldsymbol{M}$ & $\boldsymbol{S}$ & $\boldsymbol{M}$ & $\boldsymbol{S}$ & $\boldsymbol{M}$ & $\boldsymbol{S}$ \\
\hline \multirow{2}{*}{1} & 22,267 & 1,82 & 23,376 & 1,73 & 23,992 & 1,79 \\
\hline
\end{tabular}

Based on the data above, the authors can conclude that the description of the use of the movement model shows an increase in the active learning time. The author takes data three times. The average obtained active learning time was an increase, the first data was carried out at the first meeting 22,267 , the second 23,376 , and the third was 23,992 . Referring to the data, the writer assumed that there had been an increase in active learning time during the three times.

\section{CONCLUSION}

Based on the data obtained by the author, it shows that the average value is increased. The use of the movement model can be concluded to have an influence on increasing student 
active learning time. Some of the factors that can influence the active time of student learning increase is the first model used is the new model applied to students when learning takes place, so that they feel motivated. The second factor of students is directed every time, thereby reducing the chance of inactivity of each student. The next factor is the students understand the pattern of motion that is done so that they can understand and understand what must be done during the motion assignments given by the teacher.

\section{REFERENCES}

[1] J.F. Sallis, T.L. McKenzie, J.E. Alcaraz, B. Kolody, N. Faucette, and M.F. Hovell, "The effects of a 2-year physical education program (SPARK) on physical activity and fitness in elementary school students. Sports, Play and Active Recreation for Kids," Am J Public Health, vol. 87, no. (8), pp. 1328-34, 1997.
[2] M. Chung, "Investigation of Fitness Education Model ' s Implementation Effects Investigation of Fitness Education Model' $s$ Implementation Effects," J Natl Taipei Teach Coll, vol. 17, no. (1), pp. 571-84, 2004.

[3] T.A. Brusseau, J. Hannon, and R. Burns, "The Effect of a Comprehensive School Physical Activity Program on Physical Activity and Health-Related Fitness in Children from Low-Income Families," J Phys Act Health, pp. 888-94, 2016.

[4] O.A. Sinelnikov, "Sport Education for Teachers: Professional Development When Introducing a Novel Curriculum Model," Eur Phys Educ Rev, vol. 15, no. (1), pp. 91-114, 2009.

[5] M.D. Curtner-Smith, and G.A. Meek, "Teachersi Value Orientations and Their Compatibility with the National Curriculum for Physical Education," Eur Phys Educ Rev., pp. 6, no. (1), pp. 27-45, 2000.

[6] A. Suherman, The Analysis Of Character Education In Teaching Physical Education.

[7] R. Hartono, A. Suherman and A. Rusdiana, "Pengaruh Model Sport Education Terhadap Motivasi," pp. 213-26, 2014.

[8] C. Paper, R. Kurniawan, and U. Pendidikan, "Penerapan SEM (Sport Education Model) dalam Konteks Kurikulum 2013,” 2015 